\title{
An Exploration of Creative Talents Training
}

\author{
Li-juan Ren \\ International College, Bohai University, Liaoning Province 121000, China \\ Tel: 86-416-340-0215 E-mail: rlj6661@hotmail.com \\ Zheng Tang \\ Faculty of Engineering, University of Toyama, Toyama 3190, Japan \\ Tel: 81-76-445-6752 E-mail: ztang@eng.u-toyama.ac.jp
}

\begin{abstract}
The ways to train creative talents are put forward by an analysis of talents-training mode, individual development, creative thinking and the optimization of teaching process.
\end{abstract}

Keywords: creative talents, creative thinking, individuality

Innovation is the source of a nation's progress and the ever-lasting motive of a country's prosperity. Early in 1982, the Japanese government put forward that the development of creative ability should be acquired to train global, progressive and creative talents for the 21st century. Nathan Marsh Pusey, the president of Harvard University, believes that what matters to a person is whether he is a creative one. In the UK and Germany, great attention is also paid to creativity: Training creative teachers and students in creative environment.

What is creativity? There are mainly three aspects to it: First, it refers to an activity to "create totally new things" with such results as new concept, new design, new theory as well as new technology, new craftsmanship and new product; secondly, creative thinking is an activity of human beings in the process of creation; thirdly, creative talents refer to those who are of strong creativity and accustomed to creative thinking. Creative talents are confident, open-minded and more diligent, i.e. creative talents $=$ creative thinking + creative personality. Or, creative talents are closely related to one's thinking and personality.

Then, what quality should creative talents possess? First of all, they should possess creative spirit, advocate creativity, seek for creativity and be proud of creativity, and they should also be able to find the problems and raise them, i.e. "problem consciousness". Secondly, they should learn to think creatively, not being tied up to conventions and traditional concepts; they should have sharp insight and rich imagination, i.e. "preceding thinking". Thirdly, they should possess creative ability with strong and wide knowledge, broad vision, and they should also be able to open new fields by their comprehensive knowledge, and to master methodology of creating new knowledge. Fourthly, they should possess sound personality, preparing to delicate to science and human causes at any time. They should be brave to venture, to doubt and to criticize. They should also have a good balance of mental status and psychological quality.

In fact, how to train creative talents has been a common issue among world's families and schools and all walks of life. Then, how to correctly train creative talents?

\section{To train creative talents, educational thoughts must be updated and ways of training talents must be reformed.}

Human civilization is a historical development process, and it is the motive of human's creative spirit. The creative spirit is characterized by criticism, independent thinking and creative ability. Only by regarding creative spirit as a necessity of life and regarding creative ability as human existence can creative talents be trained. We must update our viewpoints on values, talents, teachers and students, transform our educational thoughts from training specialized talents to training comprehensive talents, and change our educational system from passive absorption to creative education, from knowledge-mastery students to knowledge-exploration ones, and from adaptive learning to creative learning, so that comprehensive talents will be trained with strong basis, wide knowledge and great creativity.

\section{To train creative talents, the student's individuality must be developed.}

In the whole process of education and teaching, attention should be paid to both students' knowledge acquisition and their individuality development, but they should not be confined to a fixed, dull framework. Individual education should focus on students' individual difference, in which their individual advantage should be fully played, so that they may form their own independent individuality. There are four objectives for the individuality development: the full development of personality and temperament; the good development of personal interest; the full unfolding of 
individual potential; and the effective development of individual initiatives and creativity. The individual teaching centers around classroom teaching so as to stimulate individual learning motive based on his/her knowledge structure, focuses on his/her thinking training, and makes use of message transmission and interactive activities of all senses as the guideline of teaching reform. The ultimate purpose of individual education is to train and develop students' creativity to make them become creative talents. The individuality education and teaching include the recognition of the main body, the training of independent personality and the development of individual talents. For the educators, they should teach students according to their individual situation, and for the students, they should be encouraged to display their own talents, esp. to develop their creative consciousness and creative spirit which is one of the most precious human qualities.

\section{To train creative talents, the creative thinking ability must be strengthened.}

\subsection{Independent thinking ability}

It is a must to train independent thinking ability. To train independent thinking ability, three things should be considered: bold and reasonable doubt, balance before readily accepted things, and a sound mind in self-refusal.

\subsection{The training of divergent ability}

Divergent thinking is also called difference-seeking thinking, in which answers are sought through different ways and angels. There are three levels to this kind of thinking: The first level is the smoothness in thinking - to train students' thinking speed so that they may propose more concepts and more answers in the possible shortest time. The second level is accommodation to changes - to train students' ability to accommodate themselves to different changes. The third level is novelty - the highest level in divergent thinking, i.e. to train students' ability to boldly break away from conventions and to bravely develop their creative spirit.

\subsection{The training of imagination}

Creation is a conscious imagination based on one's knowledge and experience. Hence, imagination is the starting point and necessary process for creativity. In fact, most creativity is finished by the "imagination-hypothesis - practice" process. The training of imagination should be concentrated on: (1) Hold students' curiosity to stimulate their knowledge-seeking desire; (2) Broaden their knowledge scope; (3) Make a light-hearted learning environment.

\section{To train creative talents, educational and teaching process must be optimized.}

\subsection{Reform Educational and teaching methods}

The training of creative talents depends on the creative education in school, where the educational activities are realized by teaching. So, it has been an important thing to reform educational and teaching methods. We should review the past educational and teaching methods in accordance with current social development. First, "stuffing" style of methods should be abolished in favor of enlightenment, discussion and direction style of teaching methods, in which a combination of deduction and induction should be applied to teach the students and to arouse their abilities to think, raise questions and to solve them, and students should be encouraged to create and to feel brave to have different ideas from others'. Second, practice should be emphasized to enhance the cooperation between school and all walks of life in society so as to train students' abilities to analyze the solve questions by means their comprehensive knowledge. It is necessary for students' practical abilities and foe their creative abilities and creative spirit. Third, classroom activity and after-class activity should be stressed. For one thing, classroom discussion should be promoted, which helps to stimulate students' initiatives, creativity and participation, to learn, think and explore; for another thing, after-class activity can make up for the shortage in classroom activity to encourage students to use their other abilities to the full play. Fourth, scientific research should be introduced into schooling to make teaching combined with research. For example, some research-related class may be introduced to teaching of such courses as experiment class, internship class, term paper, curriculum design, and graduation design. Of course, the students may directly participate in research activities, which is more effective in helping them to develop their creative activity.

\subsection{Reform the content of teaching and standardize the system of courses}

New development is required for the theory of curriculum and the system of courses under current situation, and the most important thing is to train students' ability to master and apply knowledge on the basis of concept building, principle mastery and course organization. First of all, the old-fashioned, redundant and valueless content of teaching should be deleted, and modern knowledge should be added in to enlarge students' vision. Secondly, the status of activity class should be improved in all the courses in school, which should focus on activities as the main teaching module centering on students with teachers playing the main role. The purpose of curricula is to teach knowledge to students, while activity class is to train their ability and to improve their quality. This is a class aimed at broadening their vision and fields to promote their initiatives and creativity. Thirdly, various selective courses should be added in to satisfy students' need in interest and ideals.

\subsection{Change viewpoint on examinations}


As an important device, examination plays a very important role in educational appraisal and human quality test. The function and aim of education is to basically improve students' ability to confront challenges and to conduct self-development. So, the content of examination should be in agreement with the above-mentioned, including the transformation from the memory of knowledge, specific comprehension and application to their ability to creatively handle with examinations. Thus, the original examination module will be changed to a fully modernized examination system.

\subsection{Build a creative team of teachers}

To train creative talents, the primary requirement for teachers is that they should be theoretical and creative type of teachers. Teachers should not be satisfied with imparting knowledge, but should participate in producing educational knowledge and creativity. They should have strong creative thinking and ability, be brave to discover new problems, participate in producing new knowledge, combine education with research, cultivate their own responsibility and scientific innovation consciousness, so that they may be theoretical and creative teachers with good influence upon their students, who learn to behave well and to create.

\section{References}

Hu, Junchen et al. (2000). Human Resources Development and Management. Fudan University Press. P. 23

Yao, Benxian. (2001). Problem Consciousness and Creativity. China Education Daily.

$\mathrm{Hu}$, Dongfang. (2003). New Thinking in New Education. Guangxi Normal University Press. P. 26

Zhou, Guoan. (2003). Enhancement of Political Ideological Education of College Students. Journal of Neijiang Teachers College.

Kang, Junying. (2005). University Focusing on Scientific Research and Personnel Fostering. Journal of Inner Mongolia Agricultural University (Social Science Edition)

Li, Li, et al. (2003). How to Cultivate Innovative Personnel. Academic Journal of Shanxi Provincial Committee Party School of C.P. C 